Kamil Kajkowski

ŚWIĘTY WOJCIECH,

URBS GYDDAANYZC I PROBLEM CHRYSTIANIZACJI

POMORZA WSCHODNIEGO.

KILKA UWAG NA MARGINESIE ROZWAŻAŃ

DOTYCZACCYCH KULTURY DUCHOWEJ

MIESZKAŃCÓW GRODU W WIDŁACH WISŁY

I MOTŁAWY

Słowa kluczowe:

Schlüisselwörter:

Keywords:
Pomorze Wschodnie, Gdańsk, święty Wojciech, chrystianizacja

Ostpommern, Gdansk, Heiliger Adalbert, Christianisierung

Western Pomerania, Gdansk, St Adalbert, Christianisation

Uroczystości związane z symboliczną datą chrztu stały się nie tylko okazją do obchodów tego ważnego dla dziejów młodego państwa piastowskiego momentu, ale przyczyniły się także do organizacji wielu sympozjów i konferencji naukowych. W ich wyniku na nowo rozgorzała dyskusja dotycząca powodu, czasu czy miejsca konwersji pierwszego historycznego władcy późniejszej Polski. Wciąż odżywające spory powodują, że nadal brak jest w nauce powszechnie akceptowanych opinii wyjaśniających okoliczności chrztu Mieszka I ${ }^{1}$.

Na pozór lepiej wygląda sytuacja dotycząca obszaru Pomorza. Jeśli ewangelizację jego zachodniej części bez większych zastrzeżeń odnieść można do misji św. Ottona z Bambergu (1124/1125 i 1128), to w przypadku wschodniej części sprawa nie wydaje się już tak oczywista. Niektórzy badacze, szczególnie w starszej literaturze, za datę chrystianizacji tego obszaru przyjmują rok 997 i łączą z misją św. Wojciecha. Jako bezpośrednie potwierdzenie takiego punktu widzenia przywołują fragment opisującego życie i misję biskupa Żywota I. Z treści

${ }^{1}$ D. A. Sikorski, Chrzest Polski i początki Kościoła w Polsce (do pierwszej połowy XI wieku), w: Chrzest - św. Wojciech - Polska. Dziedzictwo średniowiecznego Gniezna. Katalog wystawy, Gniezno 2016, ss. 25-38; P. Urbańczyk, Co się stało w 966 roku?, Poznań 2016. 
tego źródła dowiadujemy się bowiem, że Bolesław Chrobry, wspomagając działania ewangelizacyjne biskupa udającego się w drogę do Prusów „[...] daje mu łódź i dla bezpieczeństwa podczas podróży zaopatruje w trzydziestu wojów. On zaś przybył najpierw do miasta Gdańsk² położonego na skraju rozległego państwa [tego] księcia i dotykającego brzegu morza. Tu [...] gromady ludu przyjmowały chrzest" ${ }^{3}$. Przywołany passus na długie lata położył się cieniem na poglądy uczonych dotyczące konwersji Pomorza Wschodniego ${ }^{4}$. Jeszcze bardziej ugruntowały się one po publikacji rezultatów badań archeologicznych, w wyniku których ustalono, iż najstarsze nawarstwienia grodu gdańskiego można datować już na X stulecie. Przysłowiową „kropką nad i” okazał się pozyskany stąd zespół zabytków ruchomych w postaci licznych bursztynowych krzyżyków. Miały być one dowodem na przenikanie w tym czasie idei chrześcijańskich lub też bezpośrednim poświadczeniem konwersji mieszkańców grodu w czasie misji praskiego biskupa ${ }^{5}$. Wszystko więc wydawało się do siebie idealnie pasować. Nie może więc dziwić, że taka chronologia została przyjęta przez badaczy i na stałe weszła do literatury przedmiotu.

Mimo że ustalenia dotyczące tak wczesnego datowania warstw osadniczych oraz pozyskanego w takcie poszukiwań materiału archeologicznego (przede wszystkim fragmentów naczyń ceramicznych i monet) spotkały się z rzeczową krytyką ${ }^{6}$, poglądy te nie uległy rewizji.

Problem powrócił ostatnimi laty, po opublikowaniu wyników badań dendrochronologicznych drewna pozyskanego z zabudowy grodowej. Okazało się

${ }^{2}$ W zapisie oryginału urbs Gyddaanyzc - nazwa przez większość badaczy identyfikowana z Gdańskiem.

${ }^{3}$ Cyt. za: G. Labuda, Słowiańszczyzna starożytna i wczesnośredniowieczna. Antologia tekstów źródłowych, Poznań 1999, s. 234.

${ }^{4}$ Np. L. Leciejewicz, Religia pogańska i poczatki chrześcijaństwa na Pomorzu, w: Historia Pomorza, t. I, do roku 1466, cz. I, red. G. Labuda, Poznań 1972, s. 336; W. Hensel, Skąd przybyli Słowianie, Wrocław 1984, s. 96; Z. Szultka Główne linie rozwoju ludności kaszubskiej do roku 1945, w: Ludność rodzima i polska na Pomorzu Zachodnim. VIII-XX wiek, red. K. Kozłowski, Szczecin 1999, s. 13; G. Labuda Zapiski kaszubskie, pomorskie i morskie, Gdańsk 2000, ss. 189, 190-191, S. Wadyl, Pomorze Wschodnie w X wieku. Uwagi na marginesie pracy Błażeja Śliwińskiego, Początki Gdańska: dzieje ziem nad zachodnim brzegiem Zatoki Gdańskiej w I połowie X wieku, Gdańsk 2009, s. 298, Pomorania Antiqua, t. 24, 2015, ss. 556-557. Ale inaczej już T. Grudziński, Pogaństwo i chrześcijaństwo w świadomości społecznej Polski wczesnofeudalnej, w: Historia kultury średniowiecznej w Polsce. IX Powszechny Zjazd Historyków Polskich w Warszawie 13-15 września 1963 r. Referaty, red. A. Gieysztor, Warszawa 1963, s. 55.

${ }^{5}$ M. Kowalczyk, Wierzenia pogańskie za pierwszych Piastów, Łódź 1968, s. 101; B. Lepówna, Materialne przejawy wierzeń ludności Gdańska w X-XIII wieku, Pomorania Antiqua, 1981, t. 10 , s. 196; A. Wapińska, Materiały do wczesnośredniowiecznego bursztyniarstwa gdańskiego, Gdańsk Wczesnośredniowieczny, 1967, t. 6, ss. 97-98; J. Wojtasik, Bursztyniarstwo wczesnośredniowiecznego Wolina, w: Wolin wczesnośredniowieczny, cz. 1, red. B. Stanisławski, W. Filipowiak, Warszawa 2013, s. 244.

${ }^{6}$ W. Łosiński, Początki wczesnośredniowiecznego Gdańska - problem widziany z oddalenia, Slavia Antiqua, t. 41, 2001, ss. 51-54; S. Suchodolski, Numizmatyka średniowieczna. Moneta źródłem archeologicznym, historycznym i ikonograficznym, Warszawa 2012, s. 116, 122. Por. H. Paner, Rozwój przestrzenny wczesnośredniowiecznego Gdańska w świetle źródeł archeologicznych, Archaeologia Historica Polona, t. 23, 2015, ss. 142-143. 
bowiem, iż relikty elementów konstrukcyjnych fortyfikacji nie mogą być datowane wcześniej niż na drugą połowę XI w. Za oczywiste należy przyjąć zbliżone datowanie najstarszych nawarstwień osadniczych zarejestrowanych podczas dawniejszych badań wykopaliskowych ${ }^{8}$. Nie do końca przekonująca wydaje się także charakterystyka zespołu pozyskanych stąd zabytków w postaci krzyżyków występujących w kontekstach dających możliwość alternatywnego scenariusza interpretacyjnego.

Należy więc zadać pytanie, czy znany nam dzisiaj gród gdański rzeczywiście był ośrodkiem chrześcijańskim. Jeśli tak - jakie mamy na to dowody, jeśli nie - czy, gdzie i kogo chrzcił św. Wojciech podczas pobytu na Pomorzu?

W toku badań ostatnich lat wykopaliskowo udało się rozpoznać relatywnie znaczną część umocnień grodu9 . Pomijając ustalenia dotyczące szczegółów konstrukcyjnych fortyfikacji (które dla podjętych tu rozważań nie mają większego znaczenia), należy odnotować, że w wewnętrznym szeregu umocnień, w pobliżu bramy, dokonano interesującego znaleziska. Okazało się bowiem, że w jednej ze skrzyń stanowiących konstrukcję wału spoczywał szkielet psa wraz z fragmentami czterech naczyń ceramicznych. W ich wnętrzu stwierdzono pozostałości owoców poziomek, czarnych jagód, czarnego bzu, żyta oraz kąkolu i szczawiu polnego ${ }^{10}$. Charakter depozytu nie pozostawia wątpliwości, iż był to wynik intencjonalnych działań symbolicznych osadzonych w semantyce daru zakładzinowego.

W podobny sposób można interpretować szereg innych odkryć, jakich dokonano w kontekście struktur bezpośrednio związanych z umocnieniami grodu. Pierwsze, zawierające szczątki konia, odnaleziono we wschodniej części fortyfikacji, bezpośrednio pod faszyną wzmacniającą jej konstrukcję, natomiast kolejne spoczywały w izbicy wału. Szkielet konia oraz czaszki tego zwierzęcia zalegały także w okolicach północnych umocnień grodu ${ }^{11}$. Z młodszych nawarstwień tego ośrodka pochodzi kolejne znalezisko zalegające pod narożnikiem izbicy

${ }^{7}$ H. Paner, The Spatial Development of Gdansk to the beginning of the 14th Century. The Origins of the Old and Main Town, w: Polish Lands at the Turn of the First and the Second Millennia, red. P. Urbańczyk, Warszawa 2004, s. 21; B. Kościński, H. Paner, Nowe wyniki datowania grodu gdańskiego - stanowisko 1 (wyk. I-IV), w: XIV Sesja Pomorzoznawcza, t. 2: Od wczesnego średniowiecza do czasów nowożytnych, red. H. Paner, M. Fudziński, Gdańsk 2005, ss. 11-12

${ }^{8}$ R. Barnycz-Gupieniec, Planigrafia materiału zabytkowego z osady podgrodowej wczesnośredniowiecznego Gdańska (stanowisko 1), Gdańsk 2005; H. Paner, op. cit., ss. 143-144.

${ }^{9}$ Wyniki badań na obszarze Gdańska zreferował ostatnio H. Paner, op. cit., ss. 139-161.

${ }^{10}$ R. Wiloch-Kozłowska, Wyniki badań archeologicznych prowadzonych na wale grodziska gdańskiego przy ul. Grodzkiej 9 i Grodzkiej 19, w: XVIII Sesja Pomorzoznawcza, t. I, red. E. Fudzińska, Elbląg 2013, ss. 395-423; R. Wiloch-Kozłowska, B. Kościński, Wstępne wyniki badań ratowniczych prowadzonych w Gdańsku przy ulicy Grodzkiej, w: Acta Archaeologica Pomoranica III. XVI Sesja Pomorzoznawcza, Szczecin 22-24. 11. 2007 r., część I: od epoki kamienia do okresu wczesnośredniowiecznego, red. A. Janowski, K. Kowalski, S. Słowiński, Szczecin 2009, ss. 505-506.

${ }^{11}$ B. Lepówna, op. cit., ss. 183-185. 
wału. Przy czaszce końskiej tkwiło wkopane pionowo w umocnienia naczynie gliniane wypełnione makiem ${ }^{12}$.

Z reliktami umocnień wiązać można także szereg przedmiotów mogących pierwotnie manifestować wierzenia mieszkańców grodu. Zabytek w postaci lunuli odkryto w wypełnisku skrzyni wału grodowego. W podobnych okolicznościach odkryto inną jeszcze zawieszkę (?) w formie przypominającej wachlarz o rozpiętości $1 / 4$ obwodu koła. Niewykluczone, że mamy w tym przypadku do czynienia $\mathrm{z}$ fragmentem wisiorka $\mathrm{w}$ postaci miniaturowego topora ${ }^{13}$. W miejscu przebiegu umocnień obronnych grodu odkryto ponadto wykonany $\mathrm{z}$ bursztynu krzyżyk. Drugi egzemplarz wiąże się z umocnieniami lub zabudową podwałową $^{14}$. Na podstawie wyników badań archeologicznych trudno oceniać czy przedmioty te (szczególnie egzemplarze zarejestrowane w skrzyni wału) trafiły w miejsce odnalezienia w sposób przypadkowy (zguba) czy też zostały tutaj umieszczone $w$ wyniku świadomych zabiegów. $W$ obu jednak przypadkach niosły określone znaczenia dla swoich użytkowników, o czym niżej.

Znacznie większy zbiór źródeł, które można odnieść do przejawów religijności odnotowano wewnątrz umocnień grodu (por. tab. 1).

Tab. 1

Wczesnośredniowieczne znaleziska

mogące mieć związek z wierzeniami religijnymi ${ }^{15}$

\begin{tabular}{|l|l|l|l|}
\hline Lp. & \multicolumn{1}{|c|}{ Obiekt } & \multicolumn{1}{|c|}{ Opis znaleziska } & \multicolumn{1}{|c|}{ Chronologia } \\
\hline 1. & Budynek nr 1 & $\begin{array}{l}\text { Dwie zawieszki-amulety wykonane z kości zwie- } \\
\text { rzęcych. Brak bardziej szczegółowych informacji } \\
\text { dotyczących miejsca odnalezienia. }\end{array}$ & 4. XII w. \\
\hline 2. & Budynek nr 5 ${ }^{16}$ & $\begin{array}{l}\text { Czaszka zwierzęca (najprawdopodobniej dzika) } \\
\text { pod narożnikiem budynku. }\end{array}$ & 2. ćw. XII w. \\
\hline 3. & Budynek nr 6 & $\begin{array}{l}\text { Pod przyciesią ściany zalegał pozbawiony gło- } \\
\text { wy szkielet niedużego ssaka (być może psa). Po- } \\
\text { nadto w pobliżu paleniska odkryto wykonany } \\
\text { zdrewna mieczyk oraz trzy grzechotki. }\end{array}$ & \\
\hline
\end{tabular}

${ }^{12}$ Ibidem, s. 185.

${ }^{13}$ R. Wiloch-Kozłowska, op. cit., ss. 415-416.

${ }^{14}$ B. Lepówna, op. cit., s. 183. W wyniku ostatnich prac wykopaliskowych prowadzonych w rejonie fortyfikacji pozyskano kolejny okaz wykonany z bursztynu oraz zespół kilkudziesięciu zabytków metalowych odkrytych na ul. Tartacznej. Te ostatnie łączy się jednak z późniejszą zabudową podgrodową i datuje na XII-XIII stulecie (E. Drozd, Zabytki bursztynowe z grodu i osady pozyskane podczas badań przy ulicy Czopowej, Grodzkiej i Tartacznej w Gdańsku, w latach 2006-2010, w: XVIII Sesja Pomorzoznawcza, t. 2, red. E. Fudzińska, Elbląg 2013, ss. 110-111).

15 Tabela opracowana została w oparciu o publikacje: Ł. Kunicka-Okuliczowa, Wczesnośredniowieczne zabawki i gry z Gdańska, w: Gdańsk wczesnośredniowieczny, t. 1, Gdańsk 1959, ss. 107-143; B. Lepówna (op. cit., ss. 169-198).

${ }^{16}$ Interpretowany jako budynek gospodarczy. 


\begin{tabular}{|c|c|c|c|}
\hline 4. & Budynek nr 7 & $\begin{array}{l}\text { Równolegle z południowo-wschodnią ścianą za- } \\
\text { legała czaszka tura. Niewykluczone, że pierwotnie } \\
\text { mogła być przytwierdzona do szczytu budynku. }\end{array}$ & 3. ćw. XII w. \\
\hline 5. & Budynek nr 9 & $\begin{array}{l}\text { W północnym narożniku zalegała czaszka nieziden- } \\
\text { tyfikowanego zwierzęcia ułożona szczęką ku górze. }\end{array}$ & 4. ćw. XII-XII/XIII w. \\
\hline 6. & Budynek nr 13 & $\begin{array}{l}\text { Trzy zawieszki-amulety wykonane z kłów zwie- } \\
\text { rzęcych należących do bobra, lisa i niedźwiedzia. } \\
\text { Brak bardziej szczegółowych informacji doty- } \\
\text { czących miejsca odnalezienia. }\end{array}$ & 3. ćw. XII w. \\
\hline 7. & Budynek nr 16 & $\begin{array}{l}\text { Zawieszka-amulet z kła niezidentyfikowanego ga- } \\
\text { tunkowo zwierzęcia. Brak bardziej szczegółowych } \\
\text { informacji dotyczących miejsca odnalezienia. }\end{array}$ & 4. ćw. XII w. \\
\hline 8. & Budynek nr 21 & Pod północno-zachodnią ścianą zalegała czaszka tura. & 3. ćw. XII w. \\
\hline 9. & Budynek nr 26 & $\begin{array}{l}\text { Wewnątrz zabudowy zalegał krzyżyk bursztyno- } \\
\text { wy. Brak bardziej szczegółowych informacji do- } \\
\text { tyczących miejsca odnalezienia. }\end{array}$ & 3. ćw. XII w. \\
\hline 10. & Budynek nr 27 & $\begin{array}{l}\text { Pod podłogą odnaleziono liczne szczątki zwie- } \\
\text { rzęce należące do łosia, dzika, sarny, krowy i ko- } \\
\text { nia. Ponadto rybie łuski, łupiny orzechów, grudki } \\
\text { bursztynu i półfabrykat kostki bursztynowej. }\end{array}$ & 2. ćw. XII w. \\
\hline 11. & Budynek nr 37 & $\begin{array}{l}\text { Wewnątrz zabudowy odkryto krzyżyk burszty- } \\
\text { nowy. Brak bardziej szczegółowych informacji } \\
\text { dotyczących miejsca odnalezienia. }\end{array}$ & 3. ćw. XII w. \\
\hline 12. & Budynek nr 39 & $\begin{array}{l}\text { Wewnątrz zabudowy odkryto krzyżyk burszty- } \\
\text { nowy. Brak bardziej szczegółowych informacji } \\
\text { dotyczących miejsca odnalezienia. }\end{array}$ & 3. ćw. XII w. \\
\hline 13. & Budynek nr 42 & $\begin{array}{l}\text { Pod podłogą domu zalegał depozyt, na który skła- } \\
\text { dały się szczątki bobra, łosia i konia. Dodatkowo } \\
\text { umieszczono w tym miejscu szereg innych przed- } \\
\text { miotów: bursztynowy krzyżyk, wełniany woreczek, } \\
\text { kurze jajo, wianek z łyka i duży drewniany młot. }\end{array}$ & 2. ćw. XII w. \\
\hline 14. & Budynek nr 44 & $\begin{array}{l}\text { Zawieszka-amulet wykonana z kości niezidentyfiko- } \\
\text { wanego gatunkowo zwierzęcia. Brak bardziej szczegó- } \\
\text { łowych informacji dotyczących miejsca odnalezienia. }\end{array}$ & 3. ćw. XII w. \\
\hline 15. & Budynek nr 54 & $\begin{array}{l}\text { W najbliższym otoczeniu konstrukcji przyciesio- } \\
\text { wej znajdowała się czaszka końska }{ }^{17} \text {, pod podłogą } \\
\text { zarejestrowano kości kota, bobra, zająca i konia. }\end{array}$ & 2. ćw. XII w. \\
\hline
\end{tabular}

${ }^{17}$ Według opisu Barbary Lepówny, miała się ona znajdować na belce przyciesiowej. Mimo to autorka interpretuje ją jako relikt ofiary zakładzinowej. Trudno powiedzieć, na jakiej podstawie badaczka określiła pierwotne położenie czaszki odnotowanej przecież w trakcie eksploracji warstw archeologicznych. Jeśli nie jest to pomyłka, takie położenie czaszki nie może być odnoszone do aktu zakładzinowego. 


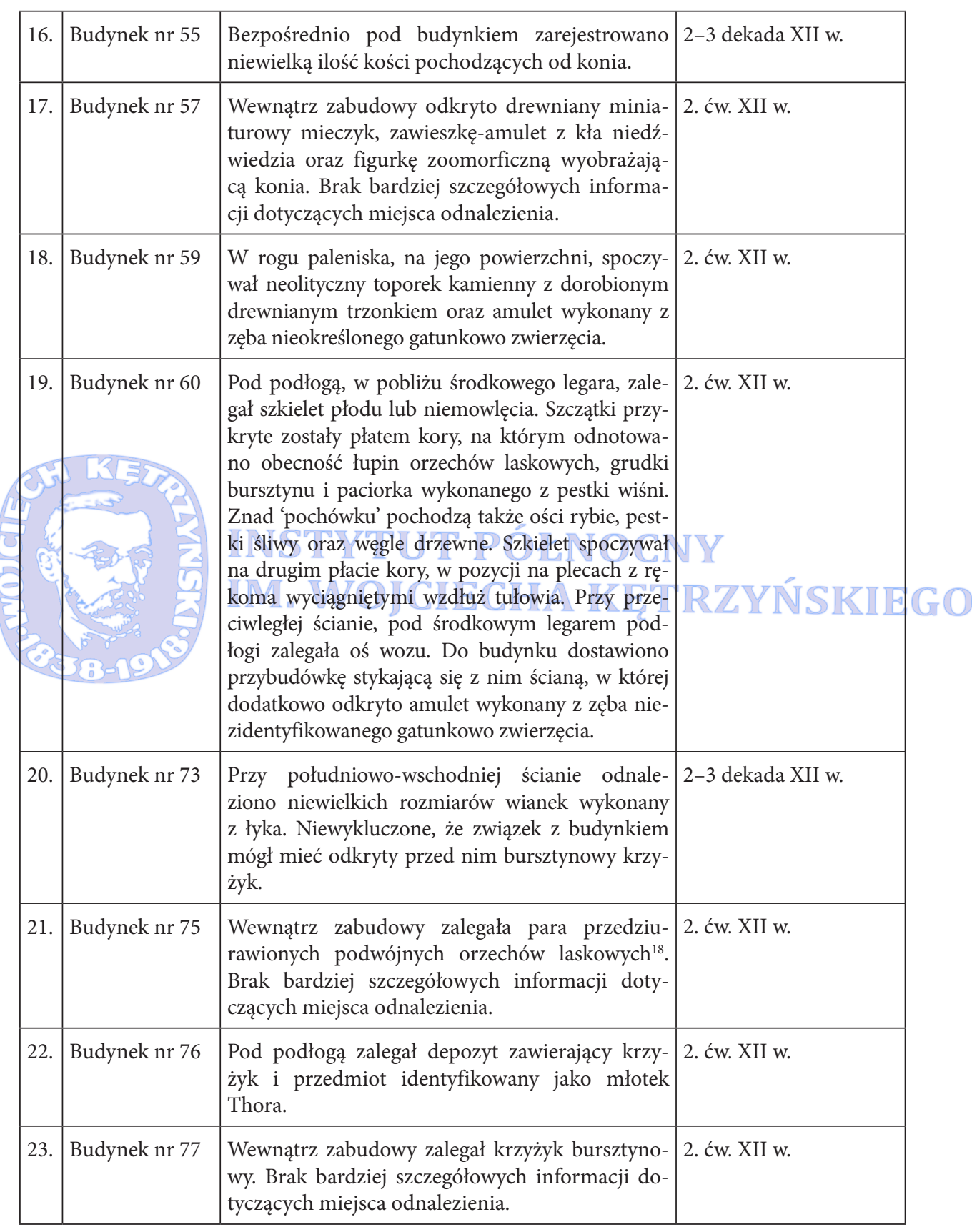

${ }^{18}$ B. Lepówna przywołuje tutaj opinię Konrada Jażdżewskiego, według którego mogły one pierwotnie pełnić funkcję zausznic. 


\begin{tabular}{|c|c|c|c|}
\hline 24. & Budynek nr 84 & $\begin{array}{l}\text { Wewnątrz zabudowy odkryto dwa, połączo- } \\
\text { ne sznurkiem, woreczki. W mniejszym zacho- } \\
\text { wała się niewielka ilość mchu, natomiast więk- } \\
\text { szy wypełniony był zawartością w postaci sie- } \\
\text { kacza bobra, pasemka czerwonych wełnianych } \\
\text { nici oraz fragmentu ornamentowanego krzyży- } \\
\text { ka wykonanego z bursztynu. Brak bardziej szcze- } \\
\text { gółowych informacji dotyczących miejsca odna- } \\
\text { lezienia. }\end{array}$ & 2-3 dekada XII w. \\
\hline 25. & Budynek nr 86 & $\begin{array}{l}\text { Bezpośrednio pod budynkiem zalegała czaszka } \\
\text { bydlęca, zaś w glinie cokołu paleniska skamieli- } \\
\text { na jeżowca oraz dwie bryłki bursztynu. }\end{array}$ & 2-3 dekada XII w. \\
\hline 26. & Budynek nr 90 & $\begin{array}{l}\text { Wewnątrz zabudowy zalegał krzyżyk bursztyno- } \\
\text { wy. Brak bardziej szczegółowych informacji do- } \\
\text { tyczących miejsca odnalezienia. }\end{array}$ & 2-3 dekada XII w. \\
\hline 27. & Budynek nr 109 & $\begin{array}{l}\text { Z wnętrza budynku pochodzi drewniana figurka } \\
\text { zoomorficzna oraz fragment łódki. Brak bardziej } \\
\text { szczegółowych informacji dotyczących miejsca } \\
\text { odnalezienia. }\end{array}$ & pocz. 2 dekady XII w. \\
\hline 28. & Budynek nr 111 & $\begin{array}{l}\text { Wewnątrz zabudowy odkryto wełnianyc wo- } \\
\text { reczek pozbawiony zawartości. Brak bardziej } \\
\text { szczegółowych informacji dotyczących miejsca } \\
\text { odnalezienia. }\end{array}$ & 1. dekada XH w. \\
\hline 29. & Budynek nr 112 & $\begin{array}{l}\text { Fragmentarycznie zachowana zawieszka-amulet } \\
\text { z siekacza bobra. Brak bardziej szczegółowych } \\
\text { informacji dotyczących miejsca odnalezienia. }\end{array}$ & pocz. 2. dekady XII w. \\
\hline 30. & Budynek nr 122 & $\begin{array}{l}\text { Z wnętrza budynku pochodzi półwytwór figurki } \\
\text { zoomorficznej. Brak bardziej szczegółowych in- } \\
\text { formacji dotyczących miejsca odnalezienia. }\end{array}$ & 1. dekada XII w. \\
\hline 31. & Budynek nr 125 & $\begin{array}{l}\text { Z wnętrza budynku pochodzi wykonana z cyny } \\
\text { kaptorga ornamentowana dwustronnym wy- } \\
\text { obrażeniem ornitomorficznym. Wnętrze kaptor- } \\
\text { gi wypełniała bliżej nie sprecyzowana masa wo- } \\
\text { skowo-żywiczna. Brak bardziej szczegółowych } \\
\text { informacji dotyczących miejsca odnalezienia. }\end{array}$ & ostatnia dekada XI w. \\
\hline 32. & Budynek nr 129 & $\begin{array}{l}\text { W reliktach zabudowy wystąpił krzyżyk sosno- } \\
\text { wy, w pobliżu którego leżał wykonany z łodyżek } \\
\text { roślin wianek. Brak bardziej szczegółowych in- } \\
\text { formacji dotyczących miejsca odnalezienia }\end{array}$ & ostatnia dekada XI w. \\
\hline 33. & Budynek nr 132 & $\begin{array}{l}\text { Wewnątrz budynku odnaleziono muszelkę „ser- } \\
\text { cówkę” z otworem do zawieszania. Brak bardziej } \\
\text { szczegółowych informacji dotyczących miejsca } \\
\text { odnalezienia. }\end{array}$ & XI-XII w. \\
\hline
\end{tabular}




\begin{tabular}{|l|l|l|l|}
\hline 34. & Budynek nr 135 & $\begin{array}{l}\text { Z wnętrza budynku pochodzi miniaturowe wy- } \\
\text { obrażenie zoomorficzne. Ponadto odkryto tutaj } \\
\text { dwa bursztynowe krzyżyki i zawieszkę interpre- } \\
\text { towaną jako młotek Thora. Brak bardziej szcze- } \\
\text { gółowych informacji dotyczących miejsca odna- } \\
\text { lezienia. }\end{array}$ & ostatnia dekada XI w. \\
\hline 35. & $\begin{array}{l}\text { Szczątkowo za- } \\
\text { chowana kon- } \\
\text { strukcja o nie- } \\
\text { ustalonej funkcji }\end{array}$ & $\begin{array}{l}\text { Czaszka konia zalegająca w bezpośredniej re- } \\
\text { lacji do elementu konstrukcyjnego - być może } \\
\text { przyciesi. }\end{array}$ & 2. ćw. XII w. \\
\hline
\end{tabular}

Powyższa tabela prezentuje grupę znalezisk, które z większym lub mniejszym prawdopodobieństwem można próbować łączyć abstrakcyjnym pojmowaniem rzeczywistości przez mieszkańców grodu. Niestety, w niektórych przypadkach pozbawieni jesteśmy bardziej szczegółowego opisu dotyczącego okoliczności i kontekstu ich odnalezienia, co w znacznym stopniu utrudnia interpretację. Nie zawsze możemy bowiem określić czy mamy do czynienia ze świadectwem intencjonalnych działań obrzędowych, manifestacją przekonan religijnych, upodobań estetycznych użytkowników poszczególnych budynków, czy też świadectwem pragmatyki codziennego życia. Z wątpliwościami dotyczącymi tych ostatnich spotykamy się przede wszystkim w trakcie analizy szczątków zwierzęcych. Jeśli te zdeponowane $\mathrm{w}$ bezpośrednim związku $\mathrm{z}$ elementami konstrukcyjnymi budynków można uznać za relikty aktów zakładzinowych, to niekoniecznie takie treści musiały kryć się za kośćmi zalegającymi pod podłogą domów ${ }^{19}$ lub takich, co do których zachodzi podejrzenie, że pierwotnie mogły znajdować się bezpośrednio na budynku. Miejsce zalegania omawianych znalezisk powoduje, że nie możemy mieć pewności czy mamy do czynienia z pozostałościami aktów religijnych, czy może odpadami gospodarczymi. Lakoniczny opis odkryć nie pozwala także ocenić czy niektóre z nich mogły być związane ze starszą zabudową i znaleźć się w takim a nie innym miejscu w wyniku niwelacji obszaru pod nowy obiekt mieszkalny. W oparciu o obecny zasób źródeł nie możemy wykluczać żadnej wersji.

Wątpliwości, co do intencjonalności depozytu mogą wzbudzać także sytuacje, w których w budynku odnotowano wyłącznie obecność zawieszek/elementów bi-

${ }^{19}$ Warto jednak zwrócić uwagę na sytuację zaobserwowaną pod podłogą domu nr 60, gdzie zalegał szkielet dziecka. Wskazuje to na możliwość symbolicznej waloryzacji również tego obszaru budynku. Niewykluczone, że pewną wskazówką mogą być również znajdowane tutaj kości konia. Wyniki badań paleozoologicznych wykazały bowiem, że zwierzę to przez mieszkańców interesującego nas osiedla nie było wykorzystywane w celach konsumpcyjnych. W związku z tym - jak sądziła Barbara Lepówna (op. cit. s. 190) - zarejestrowane w nawarstwieniach archeologicznych kości padłych koni znoszono na obszar osady z innych powodów, niekoniecznie związanych z utylitarną sferą aktywnością jej mieszkańców. Możliwe, że zbliżonych treści można dopatrywać się w zespołach przedmiotów, którym przypisuje się związek z wierzeniami religijnymi (budynki nr 42 i 76). 
żuterii. Można je bowiem postrzegać jako zguby lub/i rezultat pracy rzemieślnika trudniącego się ich wyrobem. Dopuścić można jednak i taką możliwość, że są one pozostałością potrzeb związanych z manifestacją przekonań religijnych.

W trzech przypadkach we wnętrzu zabudowy mieszkalnej zarejestrowano obecność wytworów drewnianych w postaci figurek zoomorficznych, miniaturowego miecza oraz fragmentu łódki. W interpretacji tego typu przedmiotów dominują dwie hipotezy, charakteryzujące je w kategorii zabawek lub przedmiotów związanych z myśleniem symbolicznym. Sam kontekst zalegania niektórych $\mathrm{z}$ interesujących nas $\mathrm{w}$ tym miejscu przedmiotów nie daje podstaw do wiązania ich ze sferą działań obrzędowych. Uprawdopodobniają ją jednak, jak sądzę, pewne cechy niektórych egzemplarzy, m.in. ślady świadomych działań odkryte na wyobrażeniach zoomorficznych czy umieszczony na jednej z łódek znak określany jako magiczny (choć trzeba podkreślić, że nie jest to jedyne możliwe wytłumaczenie jego funkcji), mające relatywnie liczne analogie na obszarze Słowiańszczyzny Zachodniej ${ }^{20}$.

Inną grupą zabytków, w przypadku której mogą pojawiać się wątpliwości przy charakterystyce w kontekście wierzeń religijnych, są znaleziska odnotowane w obrębie palenisk. Możemy bowiem przypuszczać, że ich obecność w miejscu odkrycia nie wynika z intencjonalnych działań, lecz z przypadku. W takim rozumieniu byłyby to przedmioty, które pierwotnie wisiały na ścianie lub leżały w pobliżu miejsca palenia ognia. Taki scenariusz jest oczywiście możliwy, trzeba jednak zwrócić uwagę na sposób rozplanowania przestrzeni wczesnośredniowiecznych budynków mieszkalnych oraz na charakter interesujących nas przedmiotów. W pierwszym przypadku należy zauważyć, że paleniska w obrębie wnętrza chat umieszczano w pewnym oddaleniu od ściany. Mogło to wynikać z potrzeb pragmatycznych: uchronienia się od pożaru (zajęcia się drewnianych ścian czy elementów wyposażenia domowego) lub/i ułatwienia dostępu do ognia w trakcie przygotowywania posiłków. Część badaczy wskazuje z kolei na inny jeszcze możliwy aspekt takiego ulokowania palenisk, wiążąc to $\mathrm{z}$ aktywnością magiczno-obrzędową wymagającą m.in. obchodzenia płomieni/żaru²1. Taki sposób interpretacji wynika z określonej waloryzacji ognia w kulturze duchowej społeczności typu tradycyjnego oraz religijności ludowej nowożytnych społeczności słowiańskich ${ }^{22}$. W tym rozumieniu treści symboliczne dotyczące tego żywiołu

\footnotetext{
${ }^{20}$ K. Kajkowski, Drobna plastyka figuralna wczesnośredniowiecznych Pomorzan - zabawki, obiekty magiczne czy rekwizyty obrzędowe?, w: Zjawiska magiczno-demoniczne na terenie dawnych ziem pruskich na tle porównawczym, red. K. Grążawski, J. Gancewski, Olsztyn 2014, ss. 221-246 (tam dyskusja i dalsza literatura).

${ }^{21}$ Por. K.W. Heckowa, Pod znakiem świętego słońca. Dawne wierzenia śląskie, Wrocław 1961, s. 106.

${ }^{22}$ Np. S. Ciszewski, Ognisko. Studium etnologiczne, Kraków 1903; M. Eliade, Sacrum, mit, historia, Warszawa 1974, s. 182; M. Kozioł, „Gość w czerwonym płaszczu”. Pogańskie i chrześcijańskie elementy w ludowym stereotypie ognia, Akcent, t. 7, nr 4, 1986, ss. 48-51; A.P. Kowalski, Słowiański rytuał tuszenia ognia i jego ślad w reliktach średniowiecznego Gdańska, Pomorania Antiqua, t. 20, 2005, s. 136.
} 
z reguły odnosi się do trzech aspektów: społecznego, w którym był jednym z elementów (np. wespół ze wspólnym biesiadowaniem) utrwalającym więzi grupowe; metafizycznego, gdzie ogień miał spełniać funkcję alegorii życia; obrzędowego, łączącego się z przekonaniem o roli ognia w kontaktach ze sferą nadprzyrodzoną ${ }^{23}$. W związku $\mathrm{z}$ tym również przedmiotom odnajdowanym $\mathrm{w}$ najbliższym otoczeniu lub wewnątrz palenisk bądź pieców przypisuje się funkcje pozautylitarne i uważa za intencjonalne depozyty umieszczane pod miejscem palenia ognia, w ścianie pieców lub wrzucane bezpośrednio do płomieni ${ }^{24}$. Nie bez znaczenia dla podjętych w tym miejscu rozważań wydaje się również fakt, iż w Gdańsku w takim kontekście zarejestrowano szereg przedmiotów, które mogą być łączone z praktykami religijnymi (przypomnę, że były to trzy grzechotki, bryłki bursztynu czy archaika w postaci neolitycznego toporka oraz skamieliny jeżowca).

$\mathrm{Z}$ obrębu wczesnośredniowiecznych nawarstwień archeologicznych tego ośrodka pochodzi także szereg innych zabytków - o być może zbliżonej funkcji - których miejsce odkrycia nie zostało powiązane z konkretnymi obiektami mieszkalno-gospodarczymi. Z obszarów niezabüdowanych pōhodzą m.in.:

- czaszka nieokreślonego gatunkowo zwierzęcia (najprawdopodobniej świni) zalegająca obok păleniska;

- wykonany z poroża krążek ${ }^{25}$. Zabytki tego rodzaju na ogół charakteryzuje się jako wieczka, elementy gier ${ }^{26}$ bądź akcesoria obrzędowe lub amulety ${ }^{27}$;

- nieokreślona liczba miniaturowych naczyń ceramicznych ${ }^{28}$. Także w tym przypadku można spotkać różne warianty interpretacyjne sprowadzające się do możliwości ujęcia ich $\mathrm{w}$ ramach przedmiotów codziennego użytku (pojemniki na zioła, wonności, przyprawy, zabawki) 29 lub wiążące je z czynnościami wynikającymi z abstrakcyjnego pojmowania rzeczywistości ${ }^{30}$. To ostatnie spostrzeżenie wynika $\mathrm{w}$ głównej mierze $\mathrm{z}$ analiz dotyczących przestrzeni funeralnych, a konkretnie wyposażenia jam grobowych, w których spotyka się miniatury naczyń ceramicznych. Część badaczy uważa nawet, że były one wykonywane przede wszystkim na potrzeby

${ }^{23}$ S. Ciszewski, op. cit.

${ }^{24}$ Por uwagi S. Suchodolskiego, op. cit., s. 207.

${ }^{25}$ M. Rulewicz, op. cit. s. 334.

${ }^{26}$ Passim.

${ }^{27}$ M. Sułowska, Jak szukaliśmy wczesnośredniowiecznej wsi, Z Otchłani Wieków, t. 38, z. 4, 1972, s. 282; Z. Váňa, Świat dawnych Słowian, Warszawa 1985, s. 93; L. Leciejewicz, Słowianie Zachodni. Z dziejów tworzenia się średniowiecznej Europy, Wrocław-Warszawa-Kraków-Gdańsk-Łódź 1989, s. 114; W. Chudziak, Items associated with mythical-religious sphere, w: The Island in Żótte on Lake Zarańskie. Early Medieval Gateway into West Pomerania, red. W. Chudziak, R. Kaźmierczak, Toruń 2014, s. 268, Fig. 6.134:b.

${ }^{28}$ Ł. Kunicka-Okuliczowa, op. cit., ss. 126-127.

${ }^{29}$ M. Rulewicz, op. cit. s. 328.

${ }^{30}$ A.P. Kowalski, O naśladowaniu i kopiach w wytwórczości prehistorycznej. Rozważania genealogiczno--antropologiczne, w: Estetyka w archeologii. Kopie i naśladownictwa, red. M. Kwapiński, Gdańsk 2006, ss. 77-79. 
rytuału pogrzebowego ${ }^{31}$. Inną przesłanką za pozautylitarną rolą tych przedmiotów mają być przypadki odkrywania ich na stanowiskach pradziejowych i wczesnośredniowiecznych w kontekście wskazującym na użycie w charakterze wotów ${ }^{32}$;

- ponad dziesięć egzemplarzy drewnianych i dwa wykonane z bursztynu ${ }^{33}$ wyobrażenia zoomorficzne ${ }^{34}$;

- kilkadziesiąt bursztynowych krzyżyków ${ }^{35}$;

- dwa drewniane mieczyki oraz drewniany nożyk w skórzanej pochewce. Próba klasyfikacji kulturowej tych przedmiotów opiera się na przesłankach zbliżonych do wspominanych wyżej niewielkich rozmiarów naczyń i wiązana jest z treściami symbolicznymi, jakie mogły być we wczesnym średniowieczu nadawane przedmiotom wykonywanym w zminiaturyzowanej skali ${ }^{36}$;

- dwa bursztynowe zabytki interpretowane jako młotki Thora ${ }^{37}$;

- przynajmniej osiemnaście zawieszek wykonanych z kości zwierzęcych (w tym z przewierconych zębów bliżej nieokreślonych zwierząt drapieżnych lub kręgów ryb)

- muszelka („sercówka”) z otworem do zawieszania ${ }^{39}$;

- niewielkie kółeczko (obrączka?, wianek?) spleciona z końskiego włosia ${ }^{40}$, mogąca spełniać rolę przedmiotu apotropaicznego (jak interpretuje się niewielkich rozmiarów wianki), może amuletu ${ }^{41}$. Niewykluczona jest również jego funkcja jako zabawki;

- miniaturowe wyobrażenie stopy/buta ${ }^{42}$ łączone z magią ochronną lub leczniczą ${ }^{43}$;

- zawieszka półksiężycowata (lunula) ${ }^{44}$;

${ }^{31} \mathrm{~J}$. Wawrzeniuk, Magia ochronna Słowian we wczesnym średniowieczu na ziemiach polskich, Warszawa 2016, s. 216 (tam dalsza literatura).

${ }^{32}$ T. Paulsson-Holmberg, Iron Age Building Offerings, Fornvínnen, t. 92, 1997, s. 171; J. Woźny, Symbolika przestrzeni miejsc grzebalnych w czasach ciałopalenia zwłok na ziemiach polskich, Bydgoszcz 2000, s. $29,73$.

${ }^{33}$ Interpretowane jako figurki psa lub konia i ptaka (jaskółki).

${ }^{34}$ A. Wapińska, op. cit., s. 96.

${ }^{35}$ B. Lepówna, op. cit., ss. 169-198.

${ }^{36}$ P.N. Kotowicz, Zabawka czy oręż ćwiczebny. Przyczynek do badań nad problematyka drewnianych naśladownictw średniowiecznych mieczy, w: Nie tylko broń. Niemilitarne wyposażenie wojowników w starożytności i średniowieczu, red. W. Świętosławski, Łódź 2008, ss. 89-98 (tam dalsza literatura).

${ }^{37}$ B. Lepówna, op. cit., s. 175.

${ }^{38}$ Ibidem, s. 175 i n.

${ }^{39}$ Ibidem, s. 175.

${ }^{40}$ Ibidem, s. 176.

${ }^{41}$ Por. A.P. Kowalski, „Swojskośc” i „obcość” w kosmologicznych i socjomorficznych wyobrażeniach dawnych Stowian, w: Swoi i obcy w kulturze średniowiecza. Wykłady popularnonaukowe zorganizowane w ramach VII Festiwalu Kultury Słowiańskiej i Cysterskiej w Lądzie nad Warta w dniach 18-19 czerwca 2011 roku, red. M. Brzostowicz, M. Przybył, J. Wrzesiński, Poznań-Ląd 2011, s. 23.

${ }^{42}$ A. Wapińska, op. cit., s. 96.

${ }^{43}$ K. Kajkowski, Woliński 'but Widara' (w druku).

${ }^{44}$ A. Koperkiewicz, „Dumne Podlasianki, dumne Mazowszanki” - o naszyjnikach na wczesnośredniowiecznych cmentarzyskach północno-wschodniej Polski, w: „In silvis, campis... et urbe”. Średniowieczny obrządek pogrzebowy na pograniczu polsko-ruskim, red. S. Cygan i in., Rzeszów-Sanok 2011, s. 268. 
- trzy gliniane grzechotki ${ }^{45}$

- siedem niewielkich rozmiarów wianków splecionych z łyka, wikliny i gałązek lub łodyg roślin ${ }^{46}$;

- fragment pisanki kijowskiej ${ }^{47}$;

- belemnit ${ }^{48}$ - chociaż nie można wykluczyć przypadkowości tego znaleziska (naturalny wtręt).

Niestety, brak czytelnego kontekstu archeologicznego wymienionych wyżej przedmiotów nie pozwala na daleko idące wnioski i zmusza do pozostania na poziomie roboczych hipotez. Jak widzieliśmy, w oparciu o pojawiające się w literaturze interpretacje, znaleziska te możemy łączyć zarówno ze sferą życia codziennego, jak myślenia w kategoriach symbolicznych. Jeśli jednak przyjmiemy związek przynajmniej części z nich ze sferą życia religijnego, to z powyższego zestawienia wyłania się obraz wyjątkowej aktywności, którą można wiązać z życiem duchowym mieszkańców grodu. Chronologia analizowanych zjawisk pozwala stwierdzić, że nie były to działania odnoszące się do określonego wycinka czasu, ale całego okresu funkcjonowania interesującego nas osiedla. Należy jednak postawić pytanie o charakter tych czynności. Innymi słowy, czy w oparciu o pozyskane źródła możemy potwierdzić hipotezę o chrystianizacji lokalnej społeczności i ocenić jej ewentualny stopień?

Mimo iż znaczna liczba analizowanych źródeł może odnosić się do tradycyjnego systemu wierzeń, to - jak wspominałem - w opinii niektórych badaczy części z tych przedmiotów (przede wszystkim zawieszki w postaci krzyżyków) ma być bezpośrednim dowodem na przenikanie idei chrześcijańskich na obszar Pomorza Wschodniego, nieobjętego jeszcze akcją misyjną. Sądzę, że analiza przynajmniej części artefaktów odkrytych na tym terenie nie daje podstaw do tak jednostronnej interpretacji i ukazuje problematykę funkcji omawianych zabytków jako bardziej złożoną. U podstaw takiego punktu widzenia leżą trzy zasadnicze kwestie: miejsce odnalezienia w obrębie budynków, charakter innych przedmiotów mogących stanowić jeden kontekst depozycyjny wraz z krzyżykami oraz przestrzeń osadnicza, w obrębie której je odnaleziono.

Jeśli dysponujemy bardziej szczegółowymi informacjami dotyczącymi miejsca zalegania krzyżyków, możemy stwierdzić, że relatywnie często odkrywano je w charakterystycznych punktach elementów konstrukcyjnych zabudowy mieszkalnej: pod przyciesią, w palenisku bądź jego najbliższym otoczeniu, pod pod-

\footnotetext{
${ }^{45}$ M. Rulewicz, op. cit., s. 232; Ł. Kunicka-Okuliczowa, op. cit., ss. 110 i n.; B. Lepówna, op. cit., s. 185.

${ }^{46}$ B. Lepówna, op. cit., ss. 175, 176, 182.

${ }^{47}$ Ibidem, s. 175.

${ }^{48}$ Ibidem, s. 184.
} 
łogą lub ścianą domu; zatem w miejscach o możliwej waloryzacji symbolicznej, odnoszonej przez badaczy do ofiar zakładzinowych ${ }^{49}$.

W kilku przypadkach wykonane z bursztynu krzyżyki mogły tworzyć jeden zespół z innymi przedmiotami niosącymi określone treści, które trudno odnosić do zwyczajów chrześcijańskich. Wydaje się, że w podobny sposób należy charakteryzować zabytek w postaci tego symbolu wykonany $z$ drewna sosnowego ${ }^{50}$.

Dla dalszych wniosków nie bez znaczenia pozostaje także spostrzeżenie, że właściwie wszystkie interesujące nas w tym miejscu przedmioty odkryto w części osadniczo-rzemieślniczej grodu. To z kolei powoduje, że trudno mówić o związku znanych dotąd zawieszek w tej formie z lokalnymi elitami - grupą społeczną będącą niemal wyłącznym odbiorcą zwyczajów i/lub wytworów stanowiących efekt napływu nowych prądów kulturowych w interesującym nas okre$\mathrm{sie}^{51}$. Co więcej, zabytki tego rodzaju są rzadkością w skali Pomorza w ogóle, co może wskazywać, że nie były one powszechnie używane przez wczesnośredniowiecznych mieszkańców tych ziem. W przypadku znalezisk gdańskich na uwagę zasługuje także fakt, iż część z nich odnotowano w obrębie reliktów budynków, które uznać można jeśli nie za pracownie bursztyniarskie, to przynajmniej za mieszkania osób zajmujących się m.in. obróbką tego surowca ${ }^{52}$. Nie można oczywiście wykluczyć, że motywy związane z recepcją symboliki krzyża płynęły $z$ inspiracji (lokalnych?) środowisk elitarnych. Niemniej jednak, biorąc pod uwagę wymowę źródeł archeologicznych, wydaje się to mało prawdopodobne. W takich bowiem okolicznościach widocznych dowodów konwersji powinniśmy oczekiwać w obrębie grodu, a tutaj ich nie stwierdzono. Argumentem za taką interpretacją może być fakt, że - przynajmniej jak do tej pory - wewnątrz pierścienia umocnień nie odnotowano nie tylko reliktów datowanej na interesujący nas okres zabudowy sakralnej, ale także artefaktów, które bezdyskusyjnie można by uznać za związane z kultem chrześcijańskim (o czym niżej).

${ }^{49}$ Por. np. J. S. Bystroń, Tematy, które mi odradzano. Pisma etnograficzne rozproszone, Warszawa 1980, s. 229; J.-F. Tuan, Przestrzeń i miejsce, Warszawa 1987, s. 136; Z. Libera, Mikrokosmos, makrokosmos i antropologia ludzkiego ciała, Tarnów 1997, s. 89; T. Paulsson-Holmberg, op. cit., s. 168; V. Lloyd, J. Dean, J. Westwood, Burn Marks as Evidence of Apotropaic Practices in Houses, Farm Buildings and Churches in Post-medieval East Anglia, w: A Permeability of Boundaries? New Approaches to the Archaeology of Art, Religion and Folklore, red. R.J. Wallis, K. Lymer, Oxford 2001, s. 69; R. Osborne, Hoards, votives, offerings: the archaeology of the dedicated object, World Archaeology, 2004, t. 36, z. 1, s. 8; J. Adamczewski, Młynarstwo magiczne, Wrocław 2005, s. 69, 76-77; S. Hukantaival, Horse Skulls and "Alder Horse": the Horse as a Depositional Sacrifice in Buildings, w: The Horse and Man in European Antiquity (Worldview, Burial Rites, and Military and Everyday Life) (Archaeologia Baltica 11), red. A. Bliujienè, Klaipėda 2009, ss. 350-351; A. P. Kowalski, op. cit., s. 22.

${ }^{50}$ Według opinii Konrada Jażdżewskiego (przyjętej także przez Lepównę), ma on stanowić bezpośredni dowód konwersji związany z misją św. Wojciecha (B. Lepówna, op. cit., s. 174).

${ }^{51}$ P. Urbańczyk, Bliskie spotkania wikingów, Wodzisław Śląski 2014, s. 108.

${ }^{52}$ B. Lepówna, op. cit., ss. 174, 178; eadem, Pracownie bursztynnicze w południowo-wschodnim rejonie gdańskiego grodu na przełomie X-XI wieku, Acta Universitatis Lodziensis, Folia Archaeologica 1992, t. 16, ss. $209-220$. 
Wiele wskazuje więc na to, że lokalne pracownie bursztyniarskie wykonywały zawieszki w formie krzyżyków albo na własny użytek (niekoniecznie w powiązaniu z wyznaniem chrześcijańskim, co sugerują egzemplarze wchodzące w skład odnotowanych tutaj depozytów), albo też z przeznaczeniem na eksport. To ostatnie spostrzeżenie wydaje się znajdować oparcie w odnoszonych do IX-XII w. znaleziskach archeologicznych odnajdowanych na obszarze Wielkich Moraw i państwa Przemyślidów. Część badaczy czeskich uważa je bowiem za importy z Pomorza, sprowadzane na potrzeby miejscowych elit ${ }^{53}$.

Najprawdopodobniej produktem wykonywanym przez miejscowych rzemieślników były także zawieszki w kształcie przypominającym młotki Thora. Większość badaczy amulety tego rodzaju łączy z kulturą Skandynawii, a ich pojawienie się z ekspansją ideologii ludów nordyckich ${ }^{54}$. Niemniej jednak, zawieszki w tej postaci, występujące na północnym wybrzeżu Bałtyku, zaczynają liczniej pojawiać się dopiero w IX stuleciu, zatem tuż przed, jak i w trakcie, misji chrystianizacyjnych podjętych na tym terenie. Spostrzeżenie to skłoniło Jörna Staeckera do konstatacji, iż duże natężenie występowania tych przēdmiotów można łączyć z reakcją środowisk pogańskich na ekspansję chrześcijaństwa ${ }^{55}$.W konsekwencji miały one podkreślać nie tylko przekonania religijne, ale także stosunki-społeczno-kulturowe/etniczne ich użytkowników. W związku z tym młotki Thora odnajdywane w osiedlach słowiańskich na południowym wybrzeżu Morza Bałtyckiego nie muszą być odbierane jako wyraz przekonań religijnych zamieszkujących te obszary społeczności nie-skandynawskich ${ }^{56}$. Mimo to, z reguły w taki właśnie sposób interpretuje się egzemplarze odnajdywane na wczesnośredniowiecznym Pomorzu. Pomijając zawieszki wchodzące w skład depozytów złomu srebrnego, ich obecność na obszarach zdominowanych przez Słowian odnotowano wyłącznie w nawarstwieniach osadniczych Wolina i Gdańska. Podczas gdy te pierwsze mogą być łączone z obcym czynnikiem kulturowym, którego obecność poświadczają tutaj zarówno źródła archeologiczne, jak i pisane, w przypadku drugich pojawiają się pewne wątpliwości, wynikające przede wszystkim z ostatnich ustaleń chronologicznych dotyczących powstania grodu w widłach Wisły i Motławy. Co więcej, nie znamy stąd odkryć archeologicznych, które wskazywałyby na intensywny obrót przedmiotami o charakterze „luksusowym”. Poza kaptorgą i lunulami, do których przyjdzie nam jeszcze powrócić, znalezio-

\footnotetext{
${ }^{53} \mathrm{~K}$. Tomková, Jantar jako doklad dálkových kontaktů v raně středověké střední Evropè, w: Pogranicza kulturowe w Europie średniowiecznej. Słowianie i ich sąsiedzi, red. K. Grążawski, M. Dulinicz, Brodnica-Warszawa-Olsztyn 2012, ss. 161-193.

${ }^{54}$ Dla zabytków gdańskich zob. B. Kosmowska-Ceranowicz, E. Choińska-Bochdan, Z bursztynem przez tysiaclecia, Gdańsk 2003, ss. 103-105.

${ }^{55}$ J. Staecker, Rex regnum et dominus dominorum. Die wikingerzeitlichen Kreuz-und Kruzifixanhänger als Ausdruck der Mission in Altdänemark und Schweden, Stockholm 1999, s. 199, ss. 213-214.

${ }^{56}$ Ibidem, s. 92.
} 
no tu jeszcze zapinkę pochodzenia skandynawskiego ${ }^{57}$. Niestety, nie dysponujemy żadnymi szczegółami dotyczącymi okoliczności jej odkrycia. Wiemy jedynie, że zabytek zarejestrowano w warstwie kulturowej datowanej obecnie na połowę drugiej dekady XII stulecia. Nie bez znaczenia dla dalszych wniosków jest także mapa rozmieszczenia najstarszych skarbów złomu srebrnego na obszarze Pomorza Gdańskiego. Z okresu przed powstaniem grodu znamy tylko dwa depozyty dirhemów ukryte w X w. (Opalenie, pow. Tczew i Oliwa II) ${ }^{58}$. Z pierwszej połowy XI stulecia pochodzą zespoły monet zakopane na kulminacji oraz w dolinie w sąsiedztwie Góry Gradowej ${ }^{59}$. Z początkową fazą funkcjonowania interesującego nas grodu wiązać można na dzień dzisiejszy dwa depozyty (oba datowane po 1068 r.): z Oruni i Ujeściska ${ }^{60}$. Nie do końca jasny pozostaje też charakter niektórych z tych odkryć, mogący wskazywać na ich charakter ekonomiczny jak i symboliczny.

Pozostawiając ten problem na marginesie rozważań wypada stwierdzić, że dostępna baza źródłowa nie daje podstaw do wniosków dotyczących ponadlokalnej pozycji ośrodka gdańskiego w tym czasie. Trudno więc mówić o istotnej roli, jaką mogli w jego funkcjonowaniu odgrywać przybysze z Eurōpy Północnej. Wobec tego nie mamy solidnych przesłanek mogących wskazywać na rozprzestrzenianie się związanego $\mathrm{z}$ nimi systemu ideologicznego, którego materialną manifestacją byłyby amulety w postaci młotków Thora. Co ważne, znajdowane w Gdańsku zawieszki tego kształtu wykonane zostały wyłącznie z bursztynu. Biorąc pod uwagę fakt, iż egzemplarze $z$ tego surowca w zasadzie nie występują na północnym wybrzeżu Bałtyku oraz pamiętając o możliwościach ich produkcji w miejscowych pracowniach, część badaczy już dawniej uznała, że nie musiały być one związane $\mathrm{z}$ obcym czynnikiem etnokulturowym61. Interpretacja tę można zaakceptować pod warunkiem, że analizowane przedmioty nie były wyobrażeniami młotka Thora per se, które wiązać można wyłącznie $z$ mitologią skandynawską ${ }^{62}$. Nie dysponujemy bowiem żadnymi argumentami mogącymi poświadczyć adaptację wierzeń nordyckich przez społeczności północnosłowiańskie. Wydaje się więc, że treści symbolicznych, jakie mogły być nadawane przez wczesnośredniowiecznych „gdańszczan” amuletom w kształcie miniaturowych wyobrażeń młota trzeba szukać gdzie indziej. Sugerują to jeszcze inne znaleziska pochodzące z tego

\footnotetext{
${ }^{57}$ J. Kmieciński, Z prac wykopaliskowych w Gdańsku w 1953 r., Dawna Kultura, t. 1, z. 1, 1954, s. 41.

${ }^{58}$ S. Suchodolski, op. cit., s. 123.

${ }^{59}$ T. i R. Kiersnowscy, Wczesnośredniowieczne skarby srebrne z Pomorza, Warszawa-Wrocław 1954, ss. 41-42; E. Choińska-Bochdan, O potrzebie badań miejsc kultu przedchrześcijańskiego na Pomorzu Wschodnim, w: Archaeologia Historica Polona, t. 13: Studia z archeologii, historii i historii architektury, red. J. Olczak, s. 149. Na zbliżony okres datuje się również skarb monet arabskich z Gdańska. Niestety nie znamy żadnych szczegółów dotyczących dokładnego miejsca i okoliczności jego odkrycia (Kiersnowscy, op. cit., ss. 45-46).

${ }^{60}$ Ibidem, ss. 42-45.

${ }^{61}$ B. Lepówna, op. cit., s. 189.

${ }^{62}$ A. Janowski, Groby komorowe w Europie Środkowo-Wschodniej. Problemy wybrane, Szczecin 2015, s. 87.
} 
ośrodka. Mam tutaj na myśli dwa naturalnej wielkości młotki, z których przynajmniej jeden można odnosić do sfery wierzeń i łączyć z fenomenem ofiary zakładzinowej. Nie można więc definitywnie wykluczyć, że znaczenia, jakie przypisywano przedmiotom w kształcie młota mogły mieć podłoże także w pogańskiej religii Pomorzan ${ }^{63}$. W literaturze przedmiotu pojawiają się też głosy odnoszące zawieszki przypominające młot bądź topór do wyobrażeń łodzi lub kotwic ${ }^{64}$. Podczas gdy w pierwszym przypadku wskazuje się na treści pogańskie, w drugim interpretuje się je w dwójnasób, łącząc albo z religią typu tradycyjnego, albo przedmiotami związanymi z wierzeniami chrześcijańskimi ${ }^{65}$.

Związku z tymi ostatnimi niektórzy badacze doszukują się także w innych zawieszkach: kaptorgach i lunulach. Znalezioną w Gdańsku kaptorgę, a ściślej sposób jej ornamentacji, zarówno Zofia Hołowińska, jak i Barbara Lepówna łączą z wyobrażeniem gołębia - chrześcijańskiego symbolu Ducha Świętego ${ }^{66}$. W literaturze zwraca się uwage, że tego rodzaju przedmioty użytkowane były przede wszystkim przez przedstawicieli środowisk elitarnych. Taka supozycja legła najpewniej u podstaw hipotezy upatrującej odmienność büdynku (nr 125), -w reliktach którego ja odnaleziono ${ }^{67}$. Pomijając brak podstaw do jej utrzymania, warto zauważyć, że związek odnajdowanych na Słowiańszczyźnie Zachodniej zawieszekew postaci kaptorg z ideologią chrześcijańską krytyce poddała już Helena Zoll-Adamikowa ${ }^{68}$. Obecnie dominuje opinia wiążąca je z recepcją zwyczajów elit zachodnioeuropejskich, jednak funkcjonalnie łączy się je z wierzeniami pogańskimi. Wynika to przede wszystkich $\mathrm{z}$ analizy zawartości tych pojemników (nasiona zbóż, fragmenty kości, włókna konopi, fragment tkaniny zabrudzony krwią, gałązki drzew etc.), którą większość badaczy odnosi do obcych chrześcijaństwu działań o charakterze performatywnym lub/i symbolicznym ${ }^{69}$.

${ }^{63}$ Por.: V. P. Darkevič, Topor kak simvol Peruna v drevnerrusskom jazyčestve, Sovetskaja archeologia, 1961, t. 4, ss. 94-102; W. Szafrański, Pradzieje religii w Polsce, Warszawa 1979, ss. 374-375; R. Zaroff Organized Pagan Cult in Kievan'. The Invention of Foreign Elite or Evolution of Local Tradition?, Studia Mythologica Slavica, 1999, t. 2, s. 68; A. Gieysztor, Mitologia Słowian, Warszawa 2006, ss. 102-103; B. Mees, Alu and Hale II: 'May Thor bless', w: Áaustrvega. Saga and East Scandinavia. The 14th International Saga Conference, Uppsala, 9th-15th August 2009, vol. 2, red. A. Ney i in., Gävle 2009, ss. 687-600.

${ }^{64}$ J. Staecker, op. cit., s. 90 (tam dalsza literatura).

${ }^{65}$ M.K. Zeiten, Amulets and Amulet Use in Viking Age Denmark, Acta Archaeologica, 1997, t. 68, ss. 32-33; D. Forstner, Świat symboliki chrześcijańskiej, Warszawa 1990, s. 427.

${ }^{66}$ Z. Hołowińska, Wczesnośredniowieczne rzemiosło złotnicze w Gdańsku, w: Gdańsk Wczesnośredniowieczny, t. 1, red. J. Kamińska, Gdańsk 1959, ss. 86-87; B. Lepówna, op. cit., s. 174. Obie badaczki przypisują zabytkowi funkcję relikwiarzyka i odnoszą bezpośrednio do akcji misyjnej św. Wojciecha.

${ }^{67}$ B. Lepówna, op. cit., s. 74.

${ }^{68}$ H. Zoll-Adamikowa, Wczesnośredniowieczne cmentarzyska szkieletowe Małopolski, cz. II. Analiza, Wrocław-Warszawa-Kraków-Gdańsk 1971, s. 98.

${ }^{69}$ W. Dzieduszycki, Kruszce w systemach wartości i wymiany społeczeństwa Polski wczesnośredniowiecznej, Poznań 1995, s. 38; A. Sztyber, Kaptorgi, Alma Mater, 2008, t. 99, s. 283; eadem, Funkcja i znaczenie kaptorg we wczesnym średniowieczu, w: Kultura materialna średniowiecza w Polsce. Życie codzienne przez pryzmat rzeczy, red. P. Kucypera, S. Wadyl, Toruń 2010, s. 48; N. Profantová, A. Šilhová, Raně středověké kaptorgy v Čechách. Analýza nálezu z hrobu č. 22 na pohřebišti Klecany II, Památky Archeologické, t. 101, 2010, ss. 283-310. 
Podobne rozbieżności interpretacyjne pojawiają się w przypadku prób charakterystyki zawieszek półksiężycowatych. Przypuszcza się, że lunule na teren Słowiańszczyzny Zachodniej trafiały w wyniku wymiany handlowej z obszarami wschodniosłowiańskimi, skąd $z$ reguły się je wywodzi ${ }^{70}$. Tam wchodziły w skład kolii (sporadycznie odnajdywanych także na ziemiach polskich), relatywnie często zawierających jeszcze zawieszki w formie krzyży. Spowodowało to ukucie teorii, wedle której amulety tego rodzaju miały znaleźć oficjalną akceptację Kościoła wschodniego. Według opinii Natalii Khamayko, w taki sposób interpretować można jedynie lunule o dwóch rogach importowane $\mathrm{z}$ obszarów śródziemnomorskich za pośrednictwem Bizancjum już od IX stulecia ${ }^{71}$, gdzie były symbolami chrześcijańskimi. Zabytki „trójrożne” z wyobrażeniem półksiężyca występującym w centralnej partii przedmiotu badaczka ta uznała za związane z tradycyjnym systemem wierzeń ${ }^{72}$. Takie też egzemplarze znamy z wykopalisk gdańskich.

Spróbujmy więc podsumować wyniki przeprowadzonej analizy źródłowej i ustosunkować się do problematyki zawartej w tytule niniejszego szkicu.

1. W czasach misji św. Wojciecha gród położony w widłach Wisły i Motławy jeszcze nie istniał. Co prawda wyniki analiz archeologicznych potwierdzaja wczésniejsze osadnictwo na tym obszarze, jednocześnie jednak wskazują, że nie było ono zbyt intensywne ${ }^{73}$. Wydaje się więc, że w X stuleciu „Gdańsk” nie mógł odgrywać istotnej roli w dystrybucji i dalekosiężnej wymianie towarów, a tym samym pełnić funkcji wyróżniającego się ośrodka w tej części Pomorza. Wskazać można tutaj nie tylko na niewielką liczbę skarbów, czy nieobecność przedmiotów luksusowych, których obrót łączony jest najczęściej z elitami społecznymi i funkcjonowaniem struktur władzy, ale również brak śladów mogących wskazywać na obrót towarem masowym. Możliwe, że pośrednio wskazywać na to może brak (przynajmniej jak do tej pory) reliktów przystani portowej zdolnej obsługiwać duże jednostki handlowe w tym czasie. Ta ostatnia uwaga jest o tyle istotna, iż - jeśli założymy wiarygodność Żywota I św. Wojciecha - w 997 r. Bolesław Chrobry wysłał biskupa wraz z towarzyszącymi mu misjonarzami do urbs Gyddaanyzc w eskorcie trzydziestu zbrojnych. Przyjmując za źródłem, iż

\footnotetext{
${ }^{70}$ H. Kočka-Krenz, Biżuteria północno-zachodnio-słowiańska we wczesnym średniowieczu, Poznań 1993, s. 95. Niemniej jednak odnalezione na niektórych stanowiskach matryce służące do odlewu lunul (Barczewko, Damice, Giecz, Płock) wydają się wskazywać, że niektóre egzemplarze mogły być produkowane przez lokalnych rzemieślników (E. Indycka, Forma odlewnicza odkryta na stanowisku 4 w Gieczu, Studia Lednickie, 2008, t. 9, ss. 221-231 (tam dalsza literatura).

${ }^{71}$ N. Khamayko, Crescent Pendants (Lunnitsa) in 11th-13th Century Rus': Pagan Amulet or Christian Ornament, w: Rome, Constantinopole and Newly-Converted Europe. Archaeological and Historical Evidence, volume II, red. M. Salamon i in., Kraków-Leipzig-Rzeszów-Warszawa 2012, ss. 503-525.

${ }^{72}$ Ibidem, s. 503; S. Małachowska, Wczesnośredniowieczne zawieszki półksiężycowate znalezione na terenie ziem polskich, Archeologia Polski, 1998, t. 43, z.1/2, s. 37.

${ }^{73}$ H. Paner, op. cit. (tam dalsza literatura).
} 
wszystkich przetransportowano jedną łodzią, musiała to być jednostka sporych rozmiarów i wymagająca aprowizacji w odpowiednich warunkach. Nie można jednak całkowicie wykluczyć, że statki mogły być rozładowywane bezpośrednio przy linii brzegowej, co - jak się wydaje - jedynie potwierdzałoby status funkcjonującego być może na tym obszarze ośrodka osadniczego.

2. Znany nam dzisiaj ośrodek położony w widłach Wisły i Motławy wedle wszelkiego prawdopodobieństwa zamieszkany był przez społeczność pogańską. Innymi słowy, nie dysponujemy przekonującymi argumentami pozwalającymi na umieszczenie w grodzie wspólnoty chrześcijańskiej. Nie dysponujemy także źródłami mogącymi wskazywać na konwersję jego mieszkańców. Wiedzieli o tym autorzy/kompilatorzy późniejszych żywotów św. Wojciecha, którzy pominęli fragment zanotowany w najstarszym źródle dotyczący konwersji Gdańska. W późniejszych zapisach grodzianie co prawda ukorzyli się pod słowami misjonarza, jednak nie byli zainteresowani recepcją nowej wiary, pozostając w rezultacie poganami. Spostrzeżenie to wydaje się mieć potwierdzenie również w innych źródłach pisanych. W datowanym na lata 1179-1183 dokumenciè wydanym przez biskupa Konrada, czytamy bowiem, że lud „który do tej pory błądził w kulcie fałszywych bogów, teraz raduje się i śpiewa poznawszy prawdziwego Boga”, a „książęta, okazawszy się skłonniejsi do czci Boga i Pana, nie zaniedbują od tej pory tępienia świętokradczych obrzędów pogańskich, przyzywają kapłanów dla oświecenia ludu"74. Ton wypowiedzi ordynariusza wskazuje, że do tej pory na obszarze podległym jego jurysdykcji wciąż dominował tradycyjny system wartości.

3. Jeżeli mielibyśmy przyjąć wiarygodność interesującego nas fragmentu Żywota I, to ośrodka, który odwiedził biskup winniśmy szukać w innym miejscu. Nie przesądzając, gdzie mógł się on znajdować, należy jednak zadać pytanie, czy przekaz tego źródła nie był efektem retoryki piśmiennictwa hagiograficznego epoki, w której powstał ${ }^{75}$. W tym kontekście musimy pamiętać o tym kto i w jakim celu tworzył takie dzieła, kto był ich potencjalnym odbiorcą. Analiza treści wczesnośredniowiecznych źródeł narracyjnych pozwala stwierdzić, że ich autorom przyświecały pobudki ideologiczne, często legitymujące aspiracje i czyny swoich mecenasów, idealizujące postaci, o których traktowały. Możliwe, że

\footnotetext{
${ }^{74}$ M. S. Szacherska, Rola klasztorów duńskich w ekspansji Danii na Pomorzu Zachodnim u schyłku XII wieku, Wrocław-Warszawa-Kraków 1968, s. 47; P. Piętkowski, Biskupstwo pomorskie jako początek biskupstwa kamieńskiego, Wrocław 2015, s. 77.

${ }^{75}$ Por. uwagi: I. Lis, Śmierć w literaturze staroserbskiej (XII-XIV wiek), Poznań 2003, s. 57; P. Wiszewski, „Domus Bolezlai". W poszukiwaniu tradycji dynastycznej Piastów (do około 1138 roku), Wrocław 2008, s. 18, 20; P. Heather, Imperia i barbarzyńcy. Migracje i narodziny Europy, Poznań 2010, s. 492; E. Domańska, P. Urbańczyk, Archeologia i historia, w: Przeszłość społeczna. Próba konceptualizacji, red. S. Tabaczyński i in., Poznań 2012, s. 858; M. Wołoszyn, Teofilakt Simokatta i Słowianie znad brzegu Oceanu Zachodniego - najstarsze świadectwo obecności Słowian nad Bałtykiem?, Kraków 2014, s. 128; S. Kadrow, Człowiek w świecie przyrody - „co się ostaje, ustanawiają poeci”, w: Gdy umiera człowiek, umiera świat cały (Funeralia Lednickie 18), red. W. Dzieduszycki, J. Wrzesiński, Poznań 2016, ss. 11-12.
} 
podobne intencje towarzyszyły także hagiografii św. Wojciecha, który nie mógł poszczycić się spektakularnymi osiągnięciami na polu działań misyjnych. Oznaczać to może, że interesujący nas zapis może być fikcyjny i stanowić tło ideologiczne dla działalności praskiego biskupa, choć na tym etapie badań trudno o pewność w tym zakresie.

Biorąc pod uwagę powyższe uwagi, można stwierdzić, że dla drugiej połowy $\mathrm{X}$ w. nie dysponujemy dowodami mogącymi wskazywać na to, że w widłach Wisły i Motławy funkcjonował jakiś ośrodek mający charakter miejsca o dużym znaczeniu politycznym i ekonomicznym. W rezultacie nie mamy podstaw, by uznać ten wycinek Pomorza za obszar wpasowujący się w model konwersji określonych mezo- i mikroregionów, gdzie celem misjonarzy były w pierwszej kolejności elity rządzące, z założenia będące gwarantem dalszych etapów skutecznych działań chrystianizacyjnych. Wszystko to powoduje, że pogląd o chrystianizacji ośrodka gdańskiego w 997 r. nie wytrzymuje krytyki. Możemy jedynie przyjąć, że u schyłku X w. biskup praski odwiedził jakiś zależny od Bolesława Chrobrego gród, w którymm/rezydował książę lub zarządca doglądający spraw monarchy i skupiający prerogatywy administracyjne interesującego nas mikroregionu. Musimy jednak pogodzić się z faktem, że - w świetle dotychczasowej wiedzy - nie wiemy ani gdzie leżał, ani jakie dokładnie odgrywał znaczenie dla społeczności pomorskich zamieszkujących estuarium dolnej Wisły. Nie mamy też żadnych podstaw pozwalających uznać, iż akt chrystianizacji związany, jak można zakładać, z najbliższym otoczeniem rezydenta tego ośrodka byłby jednoznaczny z konwersją całego wschodniego pasa Pomorza.

Kamil Kajkowski, Heiliger Adalbert, urbs Gyddaanyzc und das Problem der Christianisierung Ostpommerns. Einige Anmerkungen zu Überlegungen über die Geisteskultur der Burgbewohner in der Deltamündung von Weichsel und Mottlau

Zusammenfassung

Das Jubiläum des 1050. Jahrestages der Taufe Polens war ein guter Moment für die Wiederaufnahme der Diskussion über Gründe und Umstände der Konversion von Mieszko I. und seines werdenden Staates. Die Knappheit und Vieldeutigkeit der zugänglichen Quellen verursachen, dass es nicht leicht ist, die endgültigen Schlussfolgerungen zu formulieren. Es schien, dass in dieser Hinsicht die Situation der Konversion Pommerns besser aussieht. Zwei Christianisierungsmissionen, die sowohl den östlichen als auch den westlichen Teil des Landes betreffen, finden ein unmittelbares Echo im Schrifttum damaliger Zeit, obwohl diese Informationen in den Materialien aus archäologischen Ausgrabungen keine Widerspiegelung fanden. Während die Tätigkeit des Otto von Bamberg in Westpommern sichtbare Ergebnisse brachte, so war es im östlichen Teil des Landes

${ }^{76}$ Zdaniem Błażeja Śliwińskiego (Początki Gdańska. Dzieje ziemi nad zachodnim brzegiem Zatoki Gdańskiej w I połowie X wieku, Gdańsk 2009) hipotezy zakładające istnienie jakiegoś 'księcia gdańskiego’ nie mają uzasadnienia źródłowego i należy uznać je za mit historiograficzny. 
im 10. Jahrhundert ganz umgekehrt. Die letzten archäologischen Entdeckungen in der Burg im Weichsel- und Mottlaudelta schließen nicht nur Missionstätigkeit aus, sondern auch die Anwesenheit des heiligen Adalberts an diesem Ort. Und mehr, die archäologischen Quellen lassen vermuten, dass die Einwohner des damaligen Danzigs kein Interesse an christlichen Bräuchen zeigten, wenn sie auch zu frühmittelalterlichen Eliten gehörten (dass es sie gab, zeugen manche Entdeckungen). Davon zeugt zudem ein Korpus von Quellen, das eindeutig das Funktionieren der lokalen Gemeinschaft mit traditionellem ideologischen System zu bestätigen vermag. Kurzum, die geleisteten Entdeckungen geben keine Grundlagen für Schlussfolgerungen, sowohl zur Konversion, als auch zur Annahme, dass es hier eine christliche Gemeinschaft gab. Unter diesen Umständen muss man zugeben, dass die Überlieferungen über das Leben des heiligen Adalberts die Realität seiner Zeit nicht wiedergeben und ein ,klassisches' Beispiel der hagiographischen Rhetorik der Epoche sind, oder ein anderes Zentrum im Weichseldelta betreffen.

Übersetzt von Alina Kuzborska

\section{Kamil Kajkowski, Saint Adalbert, urbs Gyddaanyzc and chrystianisation of Western Pomerania}

Summary

The 1050 anniversary of the baptism of Poland provided a good reason to resume the current discussion on the causes and circumstances of the conversion of Mieszko I and his nascent state. The scarcity and ambiguity of available sources has meant that we are far from definitive conclusions in this regard. It would seem that we can have a better understanding regarding the conversion of Pomerania. Two missions connected sequentially with the eastern and western part of that area have had a direct echo in the literature of the early Middle Ages. And while the activity of Otto of Bamberg in Western Pomerania brought visible results (although it seems to have no such consequences as suggested by the sources) it is difficult to find evidence for the $10^{\text {th }}$ century from the eastern part of the region. Recent archaeological discoveries related to the stronghold located between the Vistula and the Motława rivers, undermine not only the possibility of missionary work in this place, but also the presence of St. Adalbert in general. Furthermore, the archaeological sources we have at our disposal suggests that the inhabitants of the Gdansk were not interested in the reception of Christian ideology - even if these were associated with early medieval elites (and the presence of their representatives here is indicated by some discoveries). It seems to be confirmed by a corpus of sources which can indicate that the functioning of the local community was based on a traditional normative system. In other words, common archaeological discoveries do not give any direct evidences concerning the stronghold's conversion, or even to place a Christian community here. In such circumstances, we must assume, that either the Vita of St Adalbert does not reflect the reality of their time and should be treated as a 'classic' example of hagiographic rhetoric, or concerns a different stronghold located at the mouth of the Vistula river.

Translated by Kamil Kajkowski

dr Kamil Kajkowski

Muzeum Zachodniokaszubskie w Bytowie

kamilkajkowski@wp.pl

Bibliografia

Adamczewski J.

2005. Młynarstwo magiczne, Wrocław.

Barnycz-Gupieniec R.

2005. Planigrafia materiału zabytkowego $z$ osady podgrodowej wczesnośredniowiecznego

Gdańska (stanowisko 1), Gdańsk. 
Bystroń J.S.

1980. Tematy które mi odradzano. Pisma etnograficzne rozproszone, Warszawa.

Ciszewski S.

1903. Ognisko. Studium etnologiczne, Kraków.

Darkevič V.P.

1961. Topor kak simvol Peruna v drevnerrusskom jazyčestve, Sovetskaja archeologia, t. 4, ss. $94-102$.

Domańska E., Urbańczyk P.

2012. Archeologia i historia, w: Przeszłość społeczna. Próba konceptualizacji, red. S. Tabaczyński i in., Poznań, ss. 852-868.

Drozd E.

2013. Zabytki bursztynowe z grodu i osady pozyskane podczas badań przy ulicy Czopowej, Grodzkiej i Tartacznej w Gdańsku, w latach 2006-2010, w: XVIII Sesja Pomorzoznawcza, t. 2, red. E. Fudzińska, Elbląg, ss. 105-113.

Dzieduszycki W.

1995. Kruszce w systemach wartości i wymiany społeczeństwa Polski wczesnośredniowiecznej, Poznań.

Choińska - Bochdan E.

2003. O potrzebie badań miejsc kultu przedchrześcijańskiego na Pomorzu Wschodnim, Archaeologia Historica Polona, t. 13: Studia $\mathrm{z}$ archeologii, historii i historii architektury, red. J. Olczak, ss. $147-152$.

Chudziak W.

2014. Items associated with mythical-religious sphere, w: The Island in Żótte on Lake Zarańskie. Early Medieval Gateway into West Pomerania, red. W. Chudziak, R. Kaźmierczak, Toruń, ss. $268-269$.

Eliade M.

1974 Sacrum, mit, historia, Warszawa.

Forstner D.

1990. Świat symboliki chrześcijańskiej, Warszawa.

Gieysztor A.

2006. Mitologia Słowian, Warszawa.

Grudziński T.

1963. Pogaństwo i chrześcijaństwo w świadomości społecznej Polski wczesnofeudalnej, w: Historia kultury średniowiecznej w Polsce. IX Powszechny Zjazd Historyków Polskich w Warszawie 13-15 września 1963 r. Referaty, red. A. Gieysztor, Warszawa, ss. 33-61.

Heckowa K.W.

1961. Pod znakiem świętego słońca. Dawne wierzenia śląskie, Wrocław.

Heather P.

2010. Imperia i barbarzyńcy. Migracje i narodziny Europy, Poznań.

Hensel W.

1984. Skąd przybyli Słowianie, Wrocław.

Hołowińska Z.

1959. Wczesnośredniowieczne rzemiosło złotnicze w Gdańsku, w: Gdańsk Wczesnośredniowieczny,

t. 1, red. J. Kamińska, Gdańsk, ss. 55-105.

Hukantaival S.

2009. Horse Skulls and "Alder Horse": the Horse as a Depositional Sacrifice in Buildings, w: The Horse and Man in European Antiquity (Worldview, Burial Rites, and Military and Everyday Life) (Archaeologia Baltica 11), red. A. Bliujienè, Klaipèda, ss. 350-356.

Indycka E.

2008. Forma odlewnicza odkryta na stanowisku 4 w Gieczu, Studia Lednickie, t. 9, ss. 221-231. 
Janowski A.

2015. Groby komorowe w Europie Środkowo-Wschodniej. Problemy wybrane, Szczecin. Kadrow S.

2016. Człowiek w świecie przyrody - „co się ostaje, ustanawiają poeci”, w: Gdy umiera człowiek, umiera świat cały (Funeralia Lednickie 18), red. W. Dzieduszycki, J. Wrzesiński, Poznań, ss. 9-18.

Kajkowski K.

2014. Drobna plastyka figuralna wczesnośredniowiecznych Pomorzan - zabawki, obiekty magiczne czy rekwizyty obrzędowe?, w: Zjawiska magiczno-demoniczne na terenie dawnych ziem pruskich na tle porównawczym, red. K. Grążawski, J. Gancewski, Olsztyn, ss. 221-246.

W druku Woliński 'but Widara'.

Khamayko N.

2012. Crescent Pendants (Lunnitsa) in 11th-13th Century Rus': Pagan Amulet or Christian Ornament,w:Rome, ConstantinopoleandNewly-ConvertedEurope.ArchaeologicalandHistorical Evidence, volume II, red. M. Salamon i in., Kraków-Leipzig-Rzeszów-Warszawa, ss. 503-525.

Kiersnowscy T. i R. Kmieciński J.

1954. Wczesnośredniowieczne skarby srebrne z Pomorza, Warszawa-Wrocław.

1954. Z prac wykopaliskowych w Gdańsku w 1953 r., Dawna Kultura, t. 1, z. 1, ss. 37-41.

Koperkiewicz A.

2011. "Dumne Podlasianki, dumne Mazowszanki"-o naszyjnikach na wczesnośredniowiecznych cmentarzyskach pótnocno-wschodniej Polski, w: „In silvis, campis... et urbe”. Średniowieczny obrzadek pogrzebowy na pograniczu polsko-ruskim, red. S. Cygan i in.,Rzeszów-Sanok, ss. 267-284.

Kosmowska-Ceranowicz B., Choińska-Bochdan E. 2003. Z bursztynem przez tysiąclecia, Gdańsk.

Kościński B., Paner H.

2005. Nowe wyniki datowania grodu gdańskiego - stanowisko 1 (wyk. I-IV), w: XIV Sesja Pomorzoznawcza, t. 2: Od wczesnego średniowiecza do czasów nowożytnych, red. H. Paner, M. Fudziński, Gdańsk, ss. 11-47.

Kotowicz P.N.

2008. Zabawka czy oręż ćwiczebny. Przyczynek do badań nad problematyka drewnianych naśladownictw średniowiecznych mieczy, w: Nie tylko broń. Niemilitarne wyposażenie wojowników w starożytności i średniowieczu, red. W. Świętosławski, Łódź, ss. 89-98.

Kowalczyk M.

1968. Wierzenia pogańskie za pierwszych Piastów, Łódź.

Kowalski A.P.

2005. Słowiański rytuał tuszenia ognia i jego ślad w reliktach średniowiecznego Gdańska, „Pomorania Antiqua”, t. 20, ss. 135-141.

2006. O naśladowaniu i kopiach w wytwórczości prehistorycznej. Rozważania genealogiczno-antropologiczne, w: Estetyka w archeologii. Kopie i naśladownictwa, red. M. Kwapiński, Gdańsk.

2011. „Swojskość" i ,obcość" w kosmologicznych i socjomorficznych wyobrażeniach dawnych Stowian, w: Swoi i obcy w kulturześredniowiecza. Wykłady popularno-naukowezorganizowane w ramach VIIFestiwalu KulturyStowiańskieji Cysterskiejw Lądzienad Wartą wdniach 18-19czerwca 2011 roku, red. M. Brzostowicz i in., Poznań-Ląd, ss. 15-30.

Kozioł M.

1986. „Gość w czerwonym płaszczu”. Pogańskie i chrześcijańskie elementy w ludowym stereotypie ognia, Akcent, t. 7, nr 4, 1986, ss. 48-51.

Kóčka-Krenz H.

1993. Biżuteria północno-zachodnio-słowiańska we wczesnym średniowieczu, Poznań. 
Kunicka-Okuliczowa $€$.

1959. Wczesnośredniowieczne zabawki i gry z Gdańska, w: Gdańsk wczesnośredniowieczny, t. 1, red. J. Kamińska, Gdańsk, ss. 107-143.

Labuda G.

1999. Słowiańszczyzna starożytna i wczesnośredniowieczna. Antologia tekstów źródłowych, Poznań.

2000. Zapiski kaszubskie, pomorskie i morskie, Gdańsk.

Leciejewicz L.

1972. Religia pogańska i początki chrześcijaństwa na Pomorzu, w: Historia Pomorza. Tom I do roku 1466, część I, red. G. Labuda, Poznań, ss. 336-338.

1989. Słowianie Zachodni. Z dziejów tworzenia się średniowiecznej Europy, Wrocław-Warszawa-Kraków-Gdańsk-Łódź.

Lepówna B.

1981. Materialne przejawy wierzeń ludności Gdańska w X-XIII wieku, Pomorania Antiqua, t. 10, ss. $169-198$.

1992. Pracownie bursztynnicze w południowo-wschodnim rejonie gdańskiego grodu na przełomie Libera Z. $X-X I$ wieku, „Acta Universitatis Lodziensis, Folia Archaeologica”, t. 16, ss. 209-220.

Lis I.

1987. Mikrokosmos, makrokosmos i antropologia ludzkiego ciała, Tarnów.

2003. Śmierć w literaturze staroserbskiej (XII-XIV wiek), Poznań.

Lloyd V., Dean J., Westwood J.

2001. Burn Marks as Evidence of Apotropaic Practices in Houses, Farm Buildings and Churches in Post-medieval East Anglia, w: A Permeability of Boundaries? New Approaches to the Archaeology of Art, Religion and Folklore, red. R.J. Wallis, K. Lymer, Oxford, ss. 57-70.

Łosiński W.

2001. Początki wczesnośredniowiecznego Gdańska - problem widziany z oddalenia, „Slavia Antiqua”, t. 41, ss. 51-62.

Małachowska S.

1998. Wczesnośredniowieczne zawieszki półksiężycowate znalezione na terenie ziem polskich, Mees B. Archeologia Polski, t. 43, z.1/2, ss. 37-127.

2009. Alu and Hale II: 'May Thor bless', w: Á austrvega. Saga and East Scandinavia. The 14th International Saga Conference, Uppsala, 9th-15th August 2009, vol. 2, red. A. Ney i in., Gävle, ss. 683-690.

Osborne R.

2004. Hoards, votives, offerings: the archaeology of the dedicated object, World Archaeology, t. 36, z. 1, ss. 1-10.

2004. The Spatial Development of Gdansk to the beginning of the 14th Century. The Origins of the Old and Main Town, w: Polish Lands at the Turn of the First and the Second Millennia, red. P. Urbańczyk, Warszawa, ss. 15-32.

2015. Rozwój przestrzenny wczesnośredniowiecznego Gdańska w świetle źródeł archeologicznych, Archaeologia Historica Polona, t. 23, ss. 139-161.

Paulsson-Holmberg T.

1997. Iron Age Building Offerings, FornvÍnnen, t. 92, ss. 163-175.

Piętkowski P.

2015. Biskupstwo pomorskie jako początek biskupstwa kamieńskiego, Wrocław.

Profantová N., Šilhová A.

2010. Raně středověké kaptorgy v Čechách. Analýza nálezu z hrobu č. 22 na pohřebišti Klecany II, Památky Archeologické, t. 101, ss. 283-310. 
Rulewicz M.

1958 Wczesnośredniowieczne zabawki i przedmioty do gier z Pomorza Zachodniego ( $z$ badań archeologicznych prowadzonych $w$ latach 1947-1958), Materiały Zachodniopomorskie, t. 4, ss. 303-354.

Sikorski D.A.

2016. Chrzest Polski i początki Kościoła w Polsce (do pierwszej połowy XI wieku), w: Chrzest - św. Wojciech - Polska. Dziedzictwo średniowiecznego Gniezna. Katalog wystawy, Gniezno, ss. $25-38$.

Staecker J.

1999. Rex regum et dominus dominorum. Die wikingerzeitlichen Kreuz-und Kruzifixanhänger als Ausdruck der Mission in Altdänemark und Schweden, Stockholm.

Suchodolski S.

2012. Numizmatyka średniowieczna. Moneta źródłem archeologicznym, historycznym i ikonograficznym, Warszawa.

Sułowska M.

1972. Jak szukaliśmy wczesnośredniowiecznej wsi, Z Otchłani Wieków, t. 38, z. 4, s. 282.

Szacherska M.S.

1968. Rola klasztorów duńskich w ekspansji Danii na Pomorzu Zachodnim u schyłku XII wieku, Wrocław-Warszawa-Kraków.

Szafrański W. 1979. Pradzieje religii w Polsce, Warszawa. $\mathrm{P} O \mathbb{I} \cup \cup \mathbb{N}$

\section{Sztyber A.}

2008. Kaptorgi, Alma Mater, t. 99, ss. 283-286.

2010 Funkcja i znaczenie kaptorg we wczesnym średniowieczu, w: Kultura materialna średniowiecza Szultka Z. w Polsce. Życie codzienne przez pryzmat rzeczy, red. P. Kucypera, S. Wadyl, Toruń, ss. 43-62.

1999. Główne linie rozwoju ludności kaszubskiej do roku 1945, w: Ludność rodzima i polska na Pomorzu Zachodnim. VIII-XX wiek, red. K. Kozłowski, Szczecin, ss. 9-47.

Śliwiński B.

2009. Początki Gdańska. Dzieje ziemi nad zachodnim brzegiem Zatoki Gdańskiej w I połowie $X$ wieku, Gdańsk.

Tomková K.

2012. Jantar jako doklad dálkových kontaktů v raně středověké střední Evropě, w: Pogranicza kulturowe w Europie średniowiecznej. Słowianie i ich sąsiedzi, red. K. Grążawski, M. Dulinicz, Brodnica-Warszawa-Olsztyn, ss. 161-193.

Tuan Y.-F.

1987. Przestrzeń i miejsce, Warszawa.

Urbańczyk P.

2014. Bliskie spotkania wikingów, Wodzisław Śląski.

2016. Co się stało w 966 roku?, Poznań.

Váňa Z.

1985. Świat dawnych Stowian, Warszawa.

Wadyl S.

2015. Pomorze Wschodnie w X wieku. Uwagi na marginesie pracy Błażeja Śliwińskiego, Początki

Gdańska: dzieje ziem nad zachodnim brzegiem Zatoki Gdańskiej w I połowie X wieku, Gdańsk 2009, ss. 298, „Pomorania Antiqua”, t. 24, ss. 537-574.

Wapińska A.

1967. Materiały do wczesnośredniowiecznego bursztyniarstwa gdańskiego, Gdańsk Wczesnośredniowieczny, t. 6, ss. 83-100. 
Wawrzeniuk J.

2016. Magia ochronna Słowian we wczesnym średniowieczu na ziemiach polskich, Warszawa.

Wiloch-Kozłowska R.

2013. Wyniki badań archeologicznych prowadzonych na wale grodziska gdańskiego przy ul. Grodzkiej 9 i Grodzkiej 19, w: XVIII Sesja Pomorzoznawcza, t. I, red. E. Fudzińska, Elbląg, ss. 395-423.

Wiloch-Kozłowska R., Kościński B.

2009. Wstępne wyniki badań ratowniczych prowadzonych w Gdańsku przy ulicy Grodzkiej, w: Acta Archaeologica Pomoranica III. XVI Sesja Pomorzoznawcza, Szczecin 22-24. 11. 2007 r., część I: od epoki kamienia do okresu wczesnośredniowiecznego, red. A. Janowski i in., Szczecin, ss. 505-512.

Wiszewski P.

2008. „Domus Bolezlai”. W poszukiwaniu tradycji dynastycznej Piastów (do około 1138 roku), Wrocław.

Wojtasik J.

2013 Bursztyniarstwo wczesnośredniowiecznego Wolina, w: Wolin wczesnośredniowieczny,

Wołoszyn M. część 1, red. B. Stanisławski, W. Filipowiak, Warszawa, ss. 235-249.

2014. Teofilakt Simokatta i Stowianie znad brzegu Oceanu Zachodniego - najstarsze świadectwo

Woźny $\mathrm{J}$. obecności Słowian nad Bałtykiem?, Kraków.

2000. Symbolika przestrzeni miejsc grzebalnych w czasach ciałopalenia zwłok na ziemiach polskich, Bydgoszcz.

Zaroff R.

1999. Organized Pagan Cult in Kievan'. The Invention of Foreign Elite or Evolution of Local Tradition?, "Studia Mythologica Slavica", t. 2, ss. 47-76.

Zeiten M.K.

1997. Amulets and Amulet Use in Viking Age Denmark, Acta Archaeologica, t. 68, ss. 1-74.

Zoll-Adamikowa $\mathrm{H}$.

1971. Wczesnośredniowieczne cmentarzyska szkieletowe Małopolski, cz. II. Analiza, Wrocław-Warszawa-Kraków-Gdańsk. 